\title{
Aberrant Extracellular Signal-Regulated Kinase (ERK) 5 Signaling in Hippocampus of Suicide Subjects
}

\author{
Yogesh Dwivedi*,', Hooriyah S Rizavi', Tara Teppen', Nobuyuki Sasaki', Hu Chen', Hui Zhang', \\ Rosalinda C Roberts ${ }^{2}$, Robert R Conley ${ }^{2}$ and Ghanshyam N Pandey' \\ 'Department of Psychiatry, Psychiatric Institute, University of Illinois at Chicago, Chicago, IL, USA; ${ }^{2}$ Maryland Psychiatric Research Center, \\ Baltimore, MD, USA
}

\begin{abstract}
Extracellular signal-regulated kinase 5 (ERK5), the newest member of the mitogen-activated protein (MAP) kinase family, is regulated differently than the other MAP kinases. Emerging evidence suggest the role of ERK5 signaling in promoting cell proliferation, differentiation, neuronal survival, and neuroprotection. The present study investigates whether suicide brain is associated with alterations in components of the ERK5 signaling cascade. In the prefrontal cortex (PFC) and hippocampus of suicide subjects ( $n=28$ ) and nonpsychiatric control subjects $(n=21)$, we examined the catalytic activities and protein levels of ERK5 and upstream MAP kinase kinase MEK5 in various subcellular fractions; mRNA levels of ERK5 in total RNA; and DNA-binding activity of myocyte enhancer factor (MEF)2C, a substrate of ERK5. In the hippocampus of suicide subjects, we observed that catalytic activity of ERK5 was decreased in cytosolic and nuclear fractions, whereas catalytic activity of MEK5 was decreased in the total fraction. Further, decreased mRNA and protein levels of ERK5, but no change in protein level of MEK5 were noted. A decrease in MEF2C-DNA-binding activity in the nuclear fraction was also observed. No significant alterations were noted in the PFC of suicide subjects. The observed changes were not related to a specific psychiatric diagnosis. Our findings of reduced activation and/or expression of ERK5 and MEK5, and reduced MEF2C-DNAbinding activity demonstrate abnormalities in ERK5 signaling in hippocampus of suicide subjects and suggest possible involvement of this aberrant signaling in pathogenic mechanisms of suicide.
\end{abstract}

Neuropsychopharmacology (2007) 32, 2338-2350; doi:I0.1038/sj.npp. I 30 I372; published online 7 March 2007

Keywords: depression; ERK5; hippocampus; human; postmortem brain; suicide

\section{INTRODUCTION}

Mitogen-activated protein kinase (MAPK) signaling cascades constitute a complex network of signaling pathways that play an essential role in the transduction of extracellular signals to cytoplasmic and nuclear effectors, and thereby regulate the genes involved in wide variety of cellular processes, including cell proliferation, differentiation, apoptosis, and synaptic plasticity (Robinson and Cobb, 1997; Johnson and Lapadat, 2002). The mitogenactivated protein (MAP) kinase pathway is composed of a highly conserved three-component cascade containing a MAPK kinase kinase, which upon activation, phosphorylates and activates MAPK kinase. The dual-specificity MAPK kinase then activates threonine and tyrosine residues in the Thr- $X$-Tyr (TXY) motif of MAPK. At least seven members of the MAPK family have been identified, which include extracellular signal-regulated kinase (ERK)-1/2,

*Correspondence: Dr Y Dwivedi, Department of Psychiatry, Psychiatric Institute, University of Illinois at Chicago, 1601 West Taylor Street, Chicago, IL 60612, USA, Tel: + I 312413 4557, Fax: + | 312355 3857, E-mail: ydwivedi@psych.uic.edu

Received 18 September 2006; revised 24 January 2007; accepted 24 January 2007
C-Jun N-terminal kinases, p38 MAPKs, Extracellular signal-regulated kinase 5 (ERK5), ERK6, and ERK7 (Garrington and Johnson, 1999; Chang and Karin, 2001; Pearson et al, 2001a).

ERK5 is the newest member of the MAPK family and is almost twice the size of other MAPKs (English et al, 1995; Lee et al, 1995; Zhou et al, 1995). It is widely expressed in many tissues, with the highest levels in the brain (Liu et al, 2003; Yan et al, 2003). In neurons, ERK5 is activated by neurotrophins, including brain-derived neurotrophic factor (BDNF), neurotrophin (NT)-3, and NT-4 (Cavanaugh et al, 2001; Watson et al, 2001; Liu et al, 2003; Shalizi et al, 2003). A number of other extracellular stimuli, such as epidermal growth factor and G-protein-coupled receptors, also activate ERK5 (Kato et al, 1998; Marinissen et al, 1999). Activation of ERK5 requires phosphorylation of Thr-219 and Tyr-221 residues by upstream MAPK kinase5 (MEK5), which in turn is activated by MEKK2, MEKK3, and Cot (Chao et al, 1999; Chiariello et al, 2000; Sun et al, 2001). ERK5, although activated by a similar Thr-Glu-Tyr dual phosphorylation motif as are ERK1/2 and ERK7, however, contains a unique loop-12 structure and an unusually large C-terminal nonkinase domain, which is absent in other types of MAPKs. This suggests that the regulation and function of this kinase may be different from that of other 
MAPKs (Lee et al, 1995; Zhou et al, 1995). ERK5 directly or indirectly phosphorylates many transcription factors, such as myocyte enhancer factor (MEF)2, c-Myc, c-Fos, c-Jun, Sapla, p90 ribosomal S6 kinase (RSK), CREB, and NF- $\kappa \mathrm{B}$ (Kato et al, 1997; English et al, 1998; Kamakura et al, 1999; Marinissen et al, 1999; Chiariello et al, 2000; Pearson et al, 2001b). ERK5 also regulates transcription, through a kinaseindependent mechanism that involves its unique C-terminal half (Kasler et al, 2000; Terasawa et al, 2003).

In recent studies, we have observed that expression of $\mathrm{BDNF}$ and of the tyrosine receptor kinase $\mathrm{B}$, to which BDNF binds and mediates its function, is reduced in postmortem brain of suicide subjects (Dwivedi et al, 2003a). Alterations in expression of other neurotrophic factors, such as NGF, $\mathrm{NT}-3$, and NT-4, in a brain region-specific manner were also noted in these subjects (Dwivedi et al, 2005). Interestingly, we found abnormalities in ERK-1/2 signaling in postmortem brain of these subjects, such that expression and activation of ERK-1/2 are decreased and expression of MAPK phosphatase1, involved in dephosphorylation and deactivation of ERK1/2, is increased (Dwivedi et al, 2001). Similar attenuation of ERK-1/2 activation has also been reported in postmortem brain of suicide subjects by Hsiung et al (2003). In addition, very recently, we reported that in ERK signaling, the upstream kinase B-Raf is less activated in postmortem brain of these subjects (Dwivedi et al, 2006). These studies clearly indicate abnormalities in neurotrophic factors and in ERK1/2 signaling in suicide subjects. Although the role of ERK5 in neuronal functions is yet to be fully established in the adult central nervous system, recent studies suggest an important role of ERK5 in neuronal survival (Cavanaugh, 2004). For example, blocking of ERK5 activation diminishes the retrograde survival response initiated by neurotrophin stimulation of axon terminals (Watson et al, 2001). In addition, it has been shown that ERK5 activation of MEF2-mediated gene expression plays a critical role in BDNF-promoted survival of developing cortical neurons (Liu et al, 2003). Yoon et al (2005) have reported that electroconvulsive shock can alter the brain region-specific activity of the ERK5-MEF2C pathway in the adult rat brain. Interestingly, in a recent study, Liu et al (2006) reported that ERK5 is necessary and sufficient to stimulate generation of neurons from cortical progenitors. Given the emerging role of ERK5 in neuronal survival/neuroprotection, the present study was undertaken to examine whether ERK5 signaling is altered in postmortem brain of suicide subjects. To this end, we examined the expression and activation of ERK5 and the functional status of MEF2C, one of the major substrates of ERK5, in the prefrontal cortex (PFC) and hippocampus of suicide subjects and normal control subjects.

\section{MATERIALS AND METHODS}

The study was performed in Brodmann's area 9 (BA9) and hippocampus obtained from suicide subjects $(n=28)$ and nonpsychiatric controls $(n=21)$, hereafter referred to as controls. Brain tissues were obtained from the Maryland Brain Collection at the Maryland Psychiatric Research Center, Baltimore, MD. Brain samples were free of any neuropathological abnormalities or HIV antibodies. Toxico- logy and presence of antidepressants were examined by analysis of urine and blood samples from these subjects. In each case, screening for the presence of HIV was performed in blood samples, and all HIV-positive cases were excluded. $\mathrm{pH}$ of the brain was measured in the cerebellum in all cases as described by Harrison et al (1995).

\section{Diagnostic Method}

At least one family member, after giving verbal informed consent, underwent an interview based on the Diagnostic Evaluation After Death (Salzman et al, 1983) and the Structured Clinical Interview for the DSM-IV (Spitzer et al, 1995). The interviews were conducted by a trained psychiatric social worker. Two psychiatrists independently reviewed the write-up from this interview, as well as the SCID that was completed from it, as part of their diagnostic assessment of the case. Diagnoses were made from the data obtained in this interview, medical records from the case, and records obtained from the Medical Examiner's office. The two diagnoses were compared and discrepancies were resolved by means of a consensus conference. Controls were verified as free from mental illnesses using these consensus diagnostic procedures. This study was approved by the IRB of the University of Illinois at Chicago.

\section{Preparation of Total and Cytosolic Fractions}

Postmortem brain tissues were homogenized in ice-cold homogenizing buffer containing $10 \mathrm{mM}$ HEPES ( $\mathrm{pH}$ 7.9), $0.5 \mathrm{mM} \mathrm{MgCl}_{2}, 10 \mathrm{mM} \mathrm{KCl}, 0.1 \mathrm{mM}$ EGTA, $0.1 \mathrm{mM}$ EDTA, $50 \mathrm{mM}$ sodium fluoride, $0.5 \mathrm{mM}$ dithiothreitol, $10 \mathrm{mM} \beta$ phosphoglycerol, $1 \mathrm{mM}$ sodium orthovanadate, $1 \% \mathrm{NP}-40$, $1 \mathrm{mM}$ benzamidine, $1 \mathrm{mM}$ phenylmethylsulfonyl fluoride (PMSF), $10 \mu \mathrm{g} / \mathrm{ml}$ leupeptin, $4 \mu \mathrm{g} / \mathrm{ml}$ aprotinin, $10 \mu \mathrm{g} / \mathrm{ml}$ pepstatin $\mathrm{A}$. The homogenate was centrifuged at $800 \mathrm{~g}$ for $10 \mathrm{~min}$ at $4{ }^{\circ} \mathrm{C}$. The supernatant was collected and used as total fraction. A portion of supernatant was removed and recentrifuged at $100000 \mathrm{~g}$ for $60 \mathrm{~min}$ at $4^{\circ} \mathrm{C}$. The supernatant was used as cytosol fraction. The protein contents in the total and cytosolic fractions were determined by the procedure of Lowry et al (1951) using bovine serum albumin as the standard.

\section{Preparation of Nuclear Extract}

Nuclear fraction was prepared according to the procedure described earlier (Dwivedi et al, 2001, 2003b). Tissues were homogenized in ice-cold buffer containing $10 \mathrm{mM}$ HEPES ( $\mathrm{pH} 7.4$ ), $1.5 \mathrm{mM} \mathrm{HCl}, 10 \mathrm{mM} \mathrm{KCl}, 2 \mathrm{mM}$ sodium pyrophosphate, $4 \mathrm{mM}$ pNPP, $2 \mathrm{mM}$ sodium orthovanadate, $1 \mathrm{mM}$ PMSF, $10 \mu \mathrm{g} / \mathrm{ml}$ leupeptin, $4 \mu \mathrm{g} / \mathrm{ml}$ aprotinin, and $10 \mu \mathrm{g} / \mathrm{ml}$ pepstatin A. The homogenate was centrifuged at $100000 \mathrm{~g}$ for $30 \mathrm{~min}$. The resulting pellet was suspended in $20 \mathrm{mM}$ HEPES ( $\mathrm{pH} 7.4$ ), $84 \mathrm{mM} \mathrm{NaCl}, 1.5 \mathrm{mM} \mathrm{MgCl}_{2}, 0.4 \mathrm{mM}$ EDTA, $50 \%$ glycerol, and protease inhibitors as above. The homogenate was incubated for $15 \mathrm{~min}$ on ice with frequent agitation, and the nuclear extracts were separated by centrifugation at $20000 \mathrm{~g}$ for $15 \mathrm{~min}$. The protein content of the nuclear extracts was determined by the method of Lowry et al (1951). 


\section{ERK5 and MEK5 Catalytic Activity Assays}

Nuclear and cytosolic (ERK5 activity) or total (MEK5 activity) fraction were subjected to immunoprecipitation by incubating with $10 \mu \mathrm{l}$ of anti-ERK5 or anti-MEK antibody (Santa Cruz Biotechnology) for $2 \mathrm{~h}$ at $4^{\circ} \mathrm{C}$, followed by $20 \mu \mathrm{l}$ of protein A-sepharose (Amersham Pharmacia Biotech) for $2 \mathrm{~h}$. Immunoprecipitates were washed three times with a buffer containing $20 \mathrm{mM}$ Tris (pH 7.5), $500 \mathrm{mM} \mathrm{NaCl}$ and $0.05 \%$ Tween 20 , and $2 \mathrm{mM}$ DTT. To detect the kinase activity, the immune complex was washed once with a reaction buffer containing $20 \mathrm{mM}$ Tris- $\mathrm{HCl}(\mathrm{pH} 7.5), 2 \mathrm{mM}$ EGTA, $2 \mathrm{mM}$ dithiothreitol, and $1 \mathrm{mM}$ PMSF and incubated for $30 \mathrm{~min}$ at $30^{\circ} \mathrm{C}$ with the substrate in a buffer (final volume, $15 \mu \mathrm{l})$ containing $20 \mathrm{mM}$ Tris- $\mathrm{HCl}(\mathrm{pH} \mathrm{7.5)}, 10 \mathrm{mM}$ $\mathrm{MgCl}_{2}$, and $100 \mu \mathrm{M}$ ATP $\left(2 \mu \mathrm{Ci}\right.$ of $\left.\left[\gamma-{ }^{32} \mathrm{P}\right] \mathrm{ATP}\right)$, and $10 \mu \mathrm{g}$ of myelin basic protein or GST-ERK5 as substrate for ERK5 or MEK5, respectively. Reaction products were separated by SDS-PAGE and visualized with autoradiography. Quantitation of ERK5 and MEK5 activities was achieved by using the Loats Image Analysis system (Westminster, MD, USA).

\section{Western Blot of ERK5 and MEK5}

Immunolabeling of ERK5 was determined in nuclear and cytosolic fractions, whereas, immunolabeling of MEK5 was determined in the total fraction by Western blot. Samples were boiled for $5 \mathrm{~min}$, vortexed, and then centrifuged for $2 \mathrm{~min}$. Equal amounts of samples $(20 \mu \mathrm{g}$ protein) were loaded on $7.5 \%(\mathrm{w} / \mathrm{v})$ polyacrylamide gel using the Mini Protein II gel apparatus (Bio-Rad Laboratories, Hercules, CA). The gels were run using $25 \mathrm{mM}$ Tris base, $192 \mathrm{mM}$ glycine, and $0.1 \%(\mathrm{w} / \mathrm{v})$ SDS at $150 \mathrm{~V}$. The proteins were subsequently transferred electrophoretically using $25 \mathrm{mM}$ Tris base, $0.2 \mathrm{M}$ glycine, and $20 \%$ methanol ( $\mathrm{pH} 8.5)$ to an enhanced chemiluminescence (ECL) nitrocellulose membrane using the Mini Trans-Blot transfer unit (Bio-Rad Laboratories) at $0.15 \mathrm{~A}$ constant current. Membranes were washed with TBST (10 mM Tris base, $0.15 \mathrm{M} \mathrm{NaC1}$, and $0.05 \%$ Tween 20 ) buffer for $5 \mathrm{~min}$. The blots were blocked by incubating with $5 \%(\mathrm{w} / \mathrm{v})$ powdered nonfat milk in TBST, $0.2 \%(\mathrm{v} / \mathrm{v})$ Nonidet P-40, and $0.02 \%(\mathrm{w} / \mathrm{v})$ SDS ( $\mathrm{pH}$ 8.0) for $1 \mathrm{~h}$ and were incubated overnight at $4{ }^{\circ} \mathrm{C}$ with primary antibody (ERK5, 1:800; MEK5, 1:500). The membranes were washed 3 times for $10 \mathrm{~min}$ each with TBST, and then membranes were incubated with HRPconjugated anti-goat secondary antibody ( $1: 1000$ dilution) for $5 \mathrm{~h}$ at room temperature. Membranes were washed 3 times, $10 \mathrm{~min}$ each with TBST. The membranes were stripped using stripping buffer (Chemicon International, Temecula) and treated with primary $\beta$-actin antibody $(1.1 \mathrm{mg} / \mathrm{ml} ; 1: 3000$ dilution) for $3 \mathrm{~h}$ and secondary HRPlinked anti-mouse antibody (1:5000 dilution) for $2 \mathrm{~h}$. $\beta$ Actin was used as a housekeeping protein to reduce interblot variability. Membranes were then incubated with a chemiluminescent detection reagent (New England Bio Labs, Inc., Beverly, MA) at room temperature. The membranes were exposed on ECL-autoradiographic films. A pooled brain extract was used in each gel as a control. Before the experiment, the dilution of the antibody and the duration of the exposure of the nitrocellulose membranes on autoradiographic film were standardized. The bands on the autoradiograms were quantified using the Loats Image Analysis System (Westminister, MD), and the optical density (OD) of each sample was corrected by the optical density of the corresponding pooled sample band. The values are presented as a percent of the control.

The specificity of each antiserum was checked by using a 100 -fold excess of blocking peptide (relative to the molarity of the antiserum) corresponding to the epitope used to generate ERK5 and MEK5. We also examined the antibodies by including positive cells (Caki-1, HeLa, A-673, and NIH3T3 whole-cell lysates) along with human frontal cortex and hippocampus for Western blot and observed that the bands in the PFC and hippocampus were of the same size as observed in cell lines. In addition, to validate our data, we initially determined the immunolabeling of ERK5 and MEK5 in the PFC and hippocampus of suicide and control subjects using five different concentrations of protein (5$50 \mu \mathrm{g})$. It was observed that the OD of the band increased linearly with increased concentration of protein and that the curve shifted toward the right when a decrease in immunolabeling was observed (data not shown).

\section{Determination of mRNA Levels of ERK5}

The procedures for RNA isolation and competitive RT-PCR analysis have been described previously (Dwivedi et al, 2001). Brain tissues were homogenized in $4 \mathrm{M}$ guanidine isothiocyanate, $50 \mathrm{mM}$ Tris/ $\mathrm{HCl}(\mathrm{pH}=7.4)$, and $25 \mathrm{mM}$ EDTA, and the total RNA was isolated by $\mathrm{CsCl}_{2}$ ultracentrifugation. The yield of total RNA was determined by measuring the absorbency of an aliquot of the precipitated stock at a wavelength of $260 / 280 \mathrm{~nm}$. Samples with a ratio below 1.8 were rejected. The degradation of mRNA was assessed using denaturing agarose gel electrophoresis and evaluating the sharpness of $28 \mathrm{~S}$ and $18 \mathrm{~S}$ rRNA bands. None of the samples used in this study showed any sign of degradation.

The quantitation of ERK5 was determined using internal standards. We also determined mRNA levels of cyclophilin, used as a housekeeping gene. Cloning and synthesis of internal standards have been described in our earlier publication. ${ }^{41}$ The primer pairs were designed to allow amplification of 88-442 base pairs (bp): forward, $5^{\prime}$ CTCTGTAGCGCCAAGAACCTG $(88-108 \mathrm{bp})$ and reverse, 5' GGATGATCTGGTGCAGGTCGC (422-442 bp) for ERK5 (GenBank accession u25278), and 118-421 bp: forward, $5^{\prime}$ AGC ACT GGA GAG AAA GGA TTT G (118-139bp) and reverse, $5^{\prime}$ CCT CCA CAA TAT TCA TGC CTT C (400$421 \mathrm{bp}$ ) for cyclophilin (GenBank accession \# XM_371409). The internal primer sequence for ERK5 was $5^{\prime}$ CCTAATGCTCTCGAGGTGGTGACC (256-279 bp). The underlined bases indicate the XhoI restriction site, whereas bold and italicized bases indicate the mutation sites. The single-strand internal primers were designed and synthesized so that the restriction site was introduced with only a minimal number of base substitutions, and also such that there was a 24-bp overlap of the primary PCR products. Each of the internal standards was synthesized in two PCR steps, starting with a cDNA template reverse transcribed from the total RNA. The internal standard templates were first cloned into a pGEM4Z vector and then amplified using M13 primers. For cyclophilin, the internal standard was 
prepared by deleting $65 \mathrm{bp}(220-237 / 303-320 \mathrm{bp})$ : 5'GGT GGC AAG TCC ATC TAT/AAA TGC TGG ACC CAA CAC.

Quantitative analyses of ERK5 and cyclophilin were performed by competitive RT-PCR as described earlier (Dwivedi et al, 2001, 2006). Decreasing concentrations of ERK5 or cyclophilin internal standard cRNAs were added to $1 \mu \mathrm{g}$ of total RNA. The PCR mixture was amplified for 26 cycles. Following amplification, aliquots were digested with XhoI (ERK5) in triplicate and run on $1.5 \%$ agarose gel. For cyclophilin, the PCR product was run directly on gel without digestion. To make sure that amplified sequences of ERK5 and cyclophilin match with the corresponding sequences reported in GenBank, the PCR products were sequenced using M13 primer.

To quantitate the amount of product corresponding to the reverse-transcribed and amplified mRNA, the ethidium bromide-stained bands were excised and counted. The results were calculated as the counts incorporated into the amplified cRNA standard divided by the counts incorporated into the corresponding mRNA amplification product $v s$ a known amount of internal standard cRNA added to the test sample. The results are expressed as attomoles $\mathrm{mRNA} / \mu \mathrm{g}$ total RNA.

\section{Determination of MEF2C-DNA-Binding Activity}

The gel mobility shift assay was performed with an oligonucleotide probe containing the MEF2C-binding sequence $\left(5^{\prime}\right.$-GATGCGTCTAAAAATAACCCTGTCG-3') (Santa Cruz Biotechnology, CA). The probe was end labeled with $\left[\gamma-{ }^{32} \mathrm{P}\right]$ ATP (Amersham Biosciences, IL) using T4 polynucleotide kinase and purified by chromatography on a column. For the DNA-protein binding reaction, the samples of nuclear extracts $(10 \mu \mathrm{g}$ of protein) were incubated with $10 \mathrm{fmol}$ of ${ }^{32} \mathrm{P}$-labeled oligonucleotide containing the consensus MEF2C-binding site at room temperature for $30 \mathrm{~min}$, in $20 \mu \mathrm{l}$ of binding buffer consisting of $20 \mathrm{mM}$ HEPES, $\mathrm{pH}$ 7.9, $0.2 \mathrm{mM}$ PMSF, $6 \%$ glycerol, and $2 \mu \mathrm{g}$ of poly(dI-dC) (Roche Molecular Biochemicals). The DNA-protein complexes were separated from the free DNA probe using electrophoresis on $7 \%$ nondenaturing polyacrylamide gels in $6.7 \mathrm{mM}$ Tris- $\mathrm{HCl}(\mathrm{pH} 7.5), 3.3 \mathrm{mM}$ sodium acetate, $0.1 \mathrm{mM}$ EDTA, and $2.5 \%$ glycerol. Gels were run at $160 \mathrm{~V}$ at $4^{\circ} \mathrm{C}$ for $3 \mathrm{~h}$, dried, then subjected to autoradiography, and analyzed with Loats Image Analysis system. To show the specificity of MEF2C-DNA-binding activity, nuclear extract from the PFC of controls was incubated in the presence of excess MEF2C antibody for $18 \mathrm{~h}$ at $4^{\circ} \mathrm{C}$, and then used for the gel mobility shift assay, which resulted in the formation of a supershift band on the gel mobility assay (data not shown). The specificity of the MEF2C-DNA-binding activity was also determined in the presence of unlabeled MEF2C consensus oligonucleotide (Santa Cruz Biotechnology, CA). The MEF2C band was completely blocked by addition of unlabeled MEF2C oligo (data not shown).

\section{Statistical Analysis}

Data analyses were performed using the SPSS 8.0 (Chicago, IL) statistical software package. All values reported are the mean $\pm S D$. The differences in various measures, age, gender, $\mathrm{pH}$ of the brain and postmortem interval (PMI), between suicide subjects and normal controls were analyzed using the independent-sample ' $t$ '-test. An $\alpha$-level less than 0.05 was considered statistically significant. The relationships between the mRNA and protein levels, as well as catalytic activity of ERK5, and PMI, age, and $\mathrm{pH}$ of the brain were determined by Pearson product-moment correlation analysis. The effects of gender on various measures were determined by an independent sample ' $t$ '-test comparing male and female subjects. Similarly, an independent sample ' $t$ '-test was used to compare depressed subjects who showed presence of antidepressant(s) during blood/urine analysis at the time of death with depressed subjects who did not. One way ANOVA was performed to examine the effect of major depression on ERK5 measures.

\section{RESULTS}

The detailed demographic characteristics of suicide subjects and controls are provided in Table 1. There were 17 male and four female subjects in the control group, and 19 male and nine female subjects in the suicide group. The age range was 21-87 years; the PMI was in the range of 5-32 h. There were no significant differences in age $(t=0.63, \mathrm{df}=47$, $P=0.53)$ or PMI $(t=0.29, \mathrm{df}=45, P=0.77)$ between suicide subjects and controls. The mean brain $\mathrm{pH}$ values of controls and suicide subjects were $6.06 \pm 0.3$ and $6.18 \pm 0.4$, respectively, which were not different between these groups $(t=1.00, \mathrm{df}=47, P=0.32)$.

\section{Catalytic Activities of MEK5 and ERK5}

The catalytic activity of MEK5 was determined in the total fraction of the PFC and hippocampus and was very similar in these two brain areas. Representative autoradiograms showing MEK5 activity in the PFC and hippocampus are given in Figure 1a, and the mean activity levels are represented in Figure $1 \mathrm{~b}$. We observed that the catalytic activity of MEK5 was significantly lower in the hippocampus $(t=5.7, \mathrm{df}=40, P<0.001)$ but not in the PFC $(t=1.3$, $\mathrm{df}=47, P=0.20)$ of suicide subjects compared with normal controls.

ERK5 has been shown to be present in the cytosol and is translocated to the nucleus upon activation (Kato et al, 1997). A recent study also suggests that ERK5 is localized in the nucleus in the resting state (Raviv et al, 2003). Therefore, ERK5 activity was determined in both cytosolic and nuclear fractions. Representative autoradiograms showing ERK5 activities in nuclear and cytosol fractions are given in Figure 2a, and mean activity levels are represented in Figure $2 \mathrm{~b}$. We observed that catalytic activity of ERK5 was higher in the hippocampus than the PFC. Also the activity of ERK5 was higher in cytosol fraction than the nuclear fraction. Comparison analysis showed that in the hippocampus of suicide subjects there was significantly lower ERK5 catalytic activity in both nuclear $(t=5.1$, $\mathrm{df}=40, P<0.001)$ and cytosolic $(t=5.2, \mathrm{df}=40, P<0.001)$ fractions compared with the activity in controls. On the other hand, no significant change was noted in ERK activity in the PFC of suicide subjects either in the nuclear $(t=1.4$, $\mathrm{df}=47, \quad P=0.17) \quad$ or the cytosolic $(t=0.56, \mathrm{df}=47$, $P=0.57)$ fraction. 
Table I Characteristics of Suicide and Control Subjects

\begin{tabular}{|c|c|c|c|c|c|c|c|c|}
\hline $\begin{array}{l}\text { Group and } \\
\text { subject }\end{array}$ & $\begin{array}{l}\text { Age } \\
\text { (years) }\end{array}$ & Race & Gender & PMI (hr) & Brain pH & Cause of death & $\begin{array}{l}\text { Drug toxicity } \\
\text { (at the time of death) }\end{array}$ & $\begin{array}{l}\text { Psychiatric } \\
\text { diagnosis }\end{array}$ \\
\hline \multicolumn{9}{|l|}{ Suicide } \\
\hline 2 & 24 & White & Male & 7 & 5.6 & GSW & Ethanol & Major depression \\
\hline 3 & 24 & White & Male & 22 & 6.5 & Hanging & None & $\begin{array}{l}\text { Schizoaffective } \\
\text { disorder }\end{array}$ \\
\hline 5 & 38 & White & Male & 24 & 6.3 & Drug overdose & Ethanol, diphenhydramine & $\begin{array}{l}\text { Major depression, } \\
\text { alcohol abuse }\end{array}$ \\
\hline 6 & 46 & White & Female & 16 & 6.1 & Drug overdose & Nortriptyline & $\begin{array}{l}\text { Major depression, } \\
\text { agoraphobia }\end{array}$ \\
\hline 9 & 22 & Black & Female & 16 & 5.3 & Drug overdose & Propranolol & Major depression \\
\hline 10 & 46 & White & Female & 21 & 5.3 & Drug overdose & $\begin{array}{l}\text { Amitriptyline, desipramine, } \\
\text { ethanol }\end{array}$ & Major depression \\
\hline | | & 50 & White & Male & 7 & 6.1 & GSW & None & No psychiatric illness \\
\hline 12 & 40 & White & Male & 26 & 5.6 & GSW & Ethanol & Adjustment disorder \\
\hline 13 & 68 & White & Female & 26 & 6.1 & GSW & Amitriptyline & Bipolar disorder \\
\hline 14 & 37 & Black & Male & NA & 5.8 & CO intoxication & Carbon monoxide & NA \\
\hline 15 & 51 & White & Female & 28 & 6.7 & Drug overdose & Amitriptyline, ethanol & Bipolar \\
\hline 16 & 30 & White & Male & 32 & 6.4 & Hanging & Cocaine, ethanol & Drug/alcohol abuse \\
\hline 17 & 24 & White & Male & 22 & 6.6 & Hanging & None & $\begin{array}{l}\text { Schizoaffective } \\
\text { disorder }\end{array}$ \\
\hline 22 & 87 & White & Male & 16 & 6.2 & GSW & None & Adjustment disorder \\
\hline 23 & 26 & Black & Male & NA & 6.5 & Hanging & Cocaine & NA \\
\hline 24 & 41 & Black & Male & 12 & 6.3 & Multiple injuries & None & No psychiatric illness \\
\hline 25 & 34 & White & Male & 16 & 6.2 & GSW & Ethanol & Alcohol abuse \\
\hline 26 & 27 & White & Male & 24 & 6.4 & GSW & None & $\begin{array}{l}\text { Major depression, } \\
\text { alcohol abuse }\end{array}$ \\
\hline 27 & 39 & White & Male & 30 & 6.5 & Asphyxia & Freon, cocaine & Drug abuse \\
\hline 28 & 36 & White & Female & 18 & 6.9 & GSW & None & Major depression \\
\hline Mean & 42.9 & 4 Black & 9 Female & 18.7 & 6.1 & & & \\
\hline SD & 13.9 & 24 White & 19 Male & 7.6 & 0.4 & & & \\
\hline \multicolumn{9}{|l|}{ Controls } \\
\hline 29 & 45 & White & Male & 22 & 6.5 & ASCVD & None & - \\
\hline 30 & 22 & Black & Male & 19 & 6.2 & GSW & None & - \\
\hline 31 & 83 & White & Male & 20 & 5.6 & ASCVD & None & - \\
\hline 32 & 63 & White & Female & 30 & 5.7 & Ovarian cancer & None & - \\
\hline 33 & 31 & Black & Male & 8 & 5.6 & GSW & None & - \\
\hline 34 & 35 & White & Male & 24 & 5.6 & Crash injury & None & - \\
\hline
\end{tabular}


Table I Continued

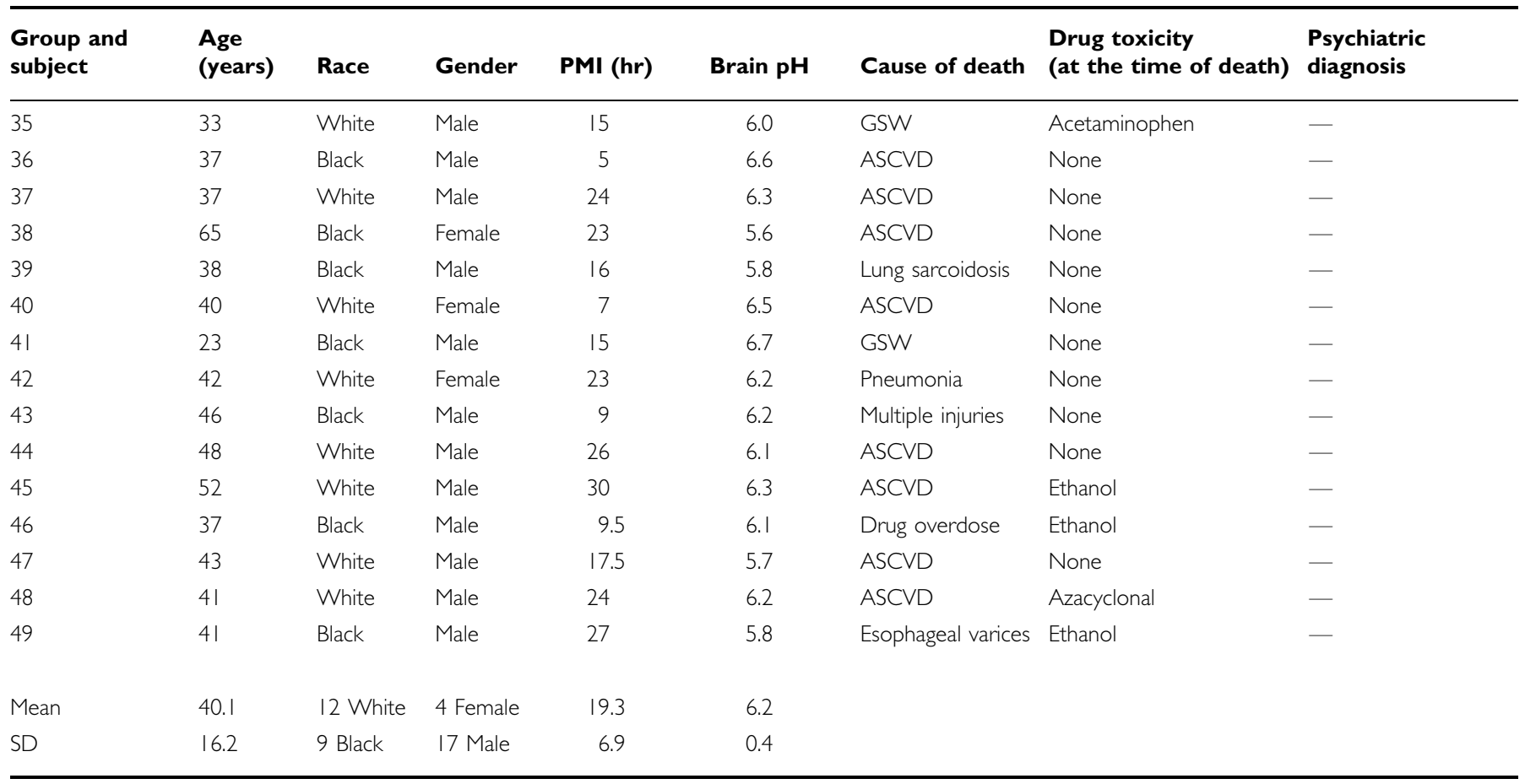

$\overline{\mathrm{ASCVD}}=$ atherosclerotic cardiovascular disease; GSW = gunshot wound; NA = not available.

a

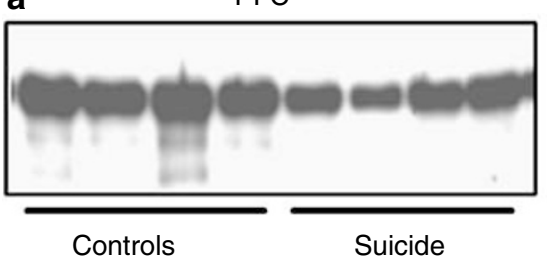

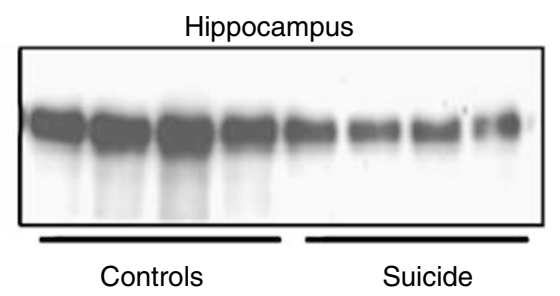

Controls

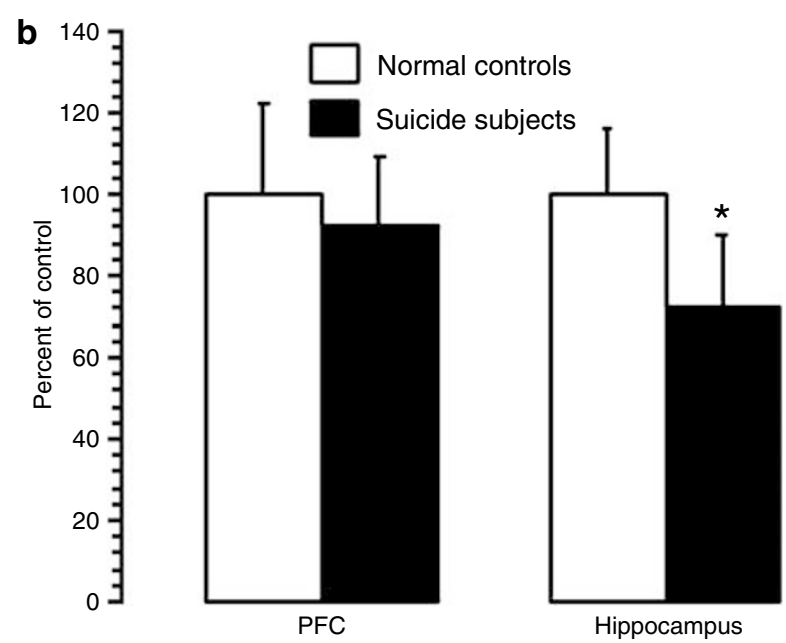

Figure I Catalytic activity of MEK5 in total fraction of the PFC and the hippocampus of suicide subjects and normal controls. (a) Representative autoradiograms showing MEK5 activity in the PFC and the hippocampus determined after immunoprecipitation using MEK5 antibody followed by incubation with GST-ERK5 and $\left[\gamma_{-}{ }^{32}\right.$ P]ATP. (b) Mean \pm SD of MEK5 catalytic activity in PFC and the hippocampus of suicide subjects and controls. PFC samples were from 21 controls and 28 suicide subjects, and the hippocampus samples were from 21 controls and 21 suicide subjects. $* P<0.001$.

\section{Immunolabeling of MEK5 and ERK5}

Immunolabeling of MEK5 (total fraction) and ERK5 (nuclear and cytosolic fractions) was examined in the same nuclear and cytosolic fractions in which their respective catalytic activities were determined. Comparison analysis showed that the level of MEK5 was not significantly altered either in the PFC $(t=67, \mathrm{df}=47, P=0.51)$ or hippocampus $(t=0.27$, $\mathrm{df}=40, P=0.78)$ of suicide subjects compared with controls. 

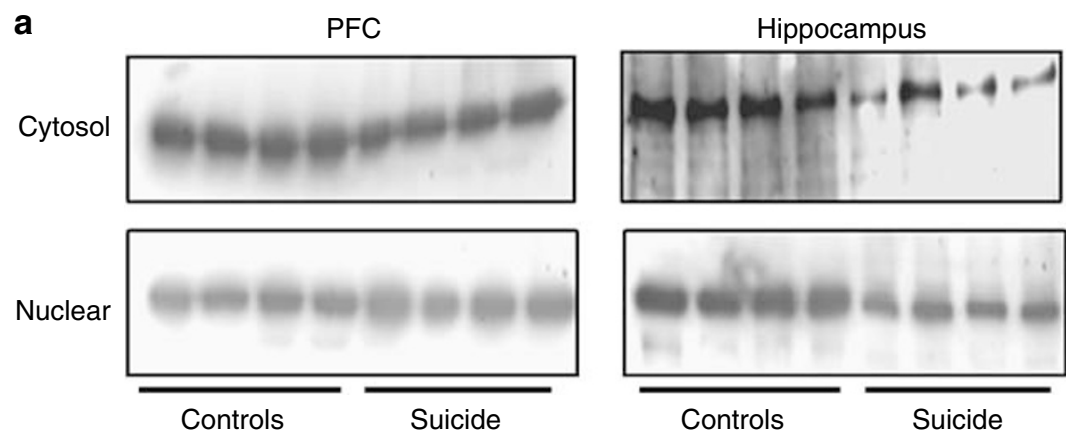

Controls Suicide
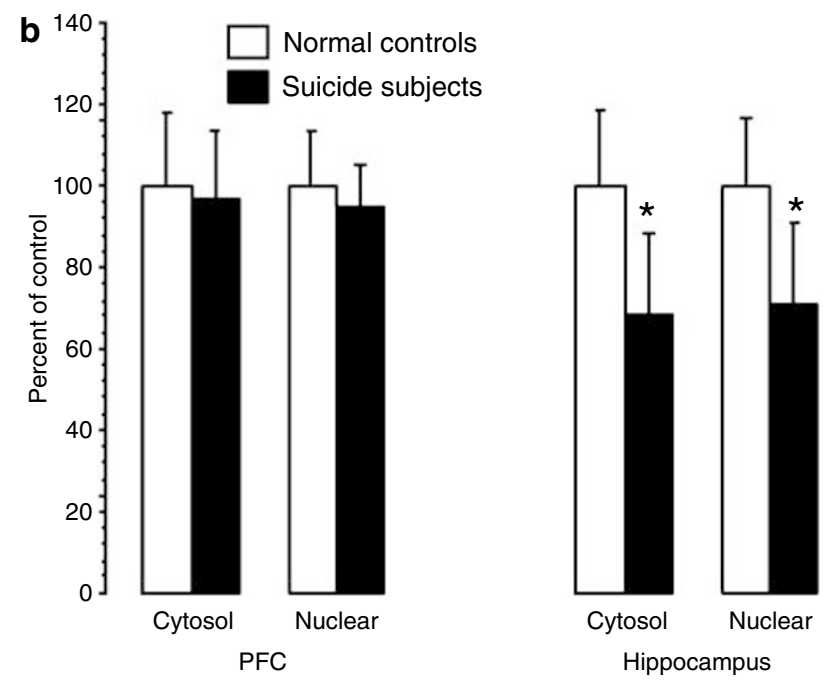

Figure 2 Catalytic activity of ERK5 in cytosolic and nuclear fractions of PFC and the hippocampus of suicide subjects and normal controls. (a) Representative autoradiograms showing ERK5 activity in cytosolic and nuclear fractions of PFC and the hippocampus determined after immunoprecipitation using ERK5 antibody followed by incubation with MBP and [ $\gamma^{32}$ P]ATP. (b) Mean \pm SD of ERK5 catalytic activities in cytosolic and nuclear fractions of PFC and the hippocampus of suicide subjects and controls. PFC samples were from 21 controls and 28 suicide subjects, and the hippocampus samples were from 21 controls and 21 suicide subjects. $* P<0.001$.

Representative Western blots for ERK5 in cytosolic and nuclear fractions obtained from PFC and hippocampus are depicted in Figure $3 a$ and $b$, respectively, whereas, bar diagrams showing the comparison of ERK5 between normal controls and suicide subjects in the PFC and hippocampus are depicted in Figure $3 \mathrm{c}$ and d, respectively. We observed that protein level of ERK5 was greater in the hippocampus than the PFC and that both hippocampus and PFC showed greater cytosolic ERK5 protein level than the nuclear ERK5 (Figure $3 \mathrm{a}$ and $\mathrm{b}$ ). It was observed that the protein level of ERK5 was significantly lower in both the nuclear $(t=4.6$, $\mathrm{df}=40, P<0.01)$ and the cytosolic $(t=2.5, \mathrm{df}=40, P=0.02)$ fraction of the hippocampus of suicide subjects (Figure 3d). On the other hand, no change was observed in protein level of ERK5 either in the nuclear $(t=0.69, \mathrm{df}=47, P=0.49)$ or the cytosolic $(t=0.56, \mathrm{df}=47, P=0.58)$ fraction of the PFC of suicide subjects compared with controls (Figure 3c).

\section{mRNA Levels of ERK5}

The mRNA level of ERK5 was determined in both the PFC and hippocampus of suicide subjects and controls by quantitative RT-PCR using internal standards. Cyclophilin mRNA was determined in these brain areas as a house- keeping gene, and ratios of ERK5 mRNA $v s$ cyclophilin mRNA were calculated. A representative gel electrophoresis showing the competitive RT-PCR for ERK5 in total RNA isolated from the PFC of one normal is given in Figure $4 \mathrm{a}$, whereas a competitive PCR analysis of ERK5 is given in Figure $4 \mathrm{~b}$. It was observed that the amplification products for ERK5 and cyclophilin arise from the mRNA template at 355 and $304 \mathrm{bp}$, respectively. The digestion products from ERK5 and cyclophilin arise from cRNA at $180+175$ and $239 \mathrm{bp}$, respectively.

Comparison of ERK5 in the PFC and hippocampus showed that the mRNA level of ERK5 was significantly reduced in the hippocampus $(t=6.98, \mathrm{df}=40, P<0.001)$ but not in the PFC $(t=0.15, \mathrm{df}=47, P=0.88)$ of suicide subjects compared with normals (Figure $4 c$ ).

We have used cyclophilin as housekeeping gene in our earlier studies and found no significant differences between normal controls and suicide subjects (Dwivedi et al, 2006). In this study, we also did not find a significant difference in cyclophilin mRNA between these two groups either in the PFC (controls: $776.66 \pm 112.5$, suicide: $801.53 \pm 117.34$ attomoles/ $\mu$ g total RNA; $t=0.74, \mathrm{df}=47, P=0.46$ ) or in the hippocampus (controls: $783.47 \pm 110.12$, suicide: $768.34 \pm 102.76$ attomoles/ $\mu$ g total RNA; $t=0.46, \mathrm{df}=40, P=0.65$ ). 
a
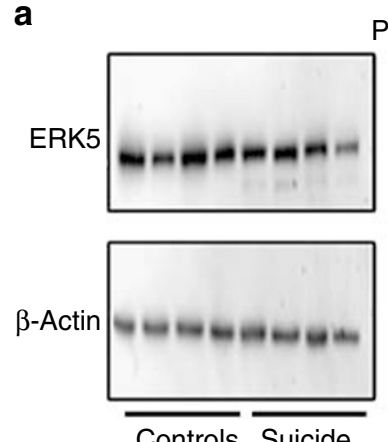

Controls Suicide

b
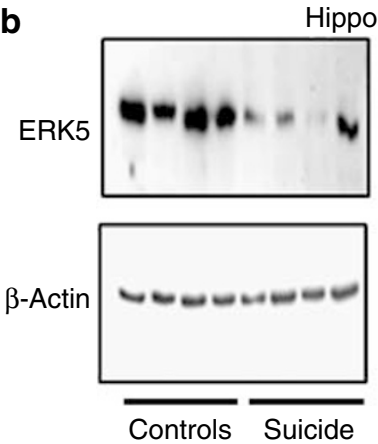

Cytosol
PFC
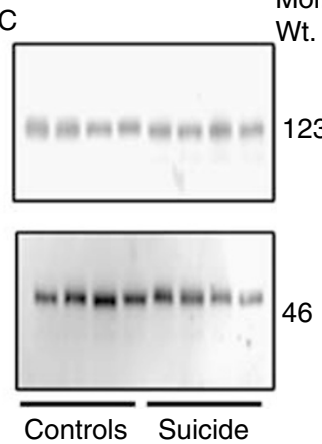

Controls Suicide
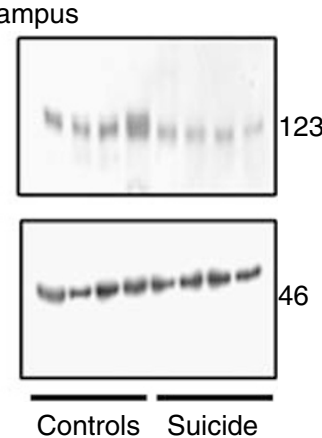

Nuclear

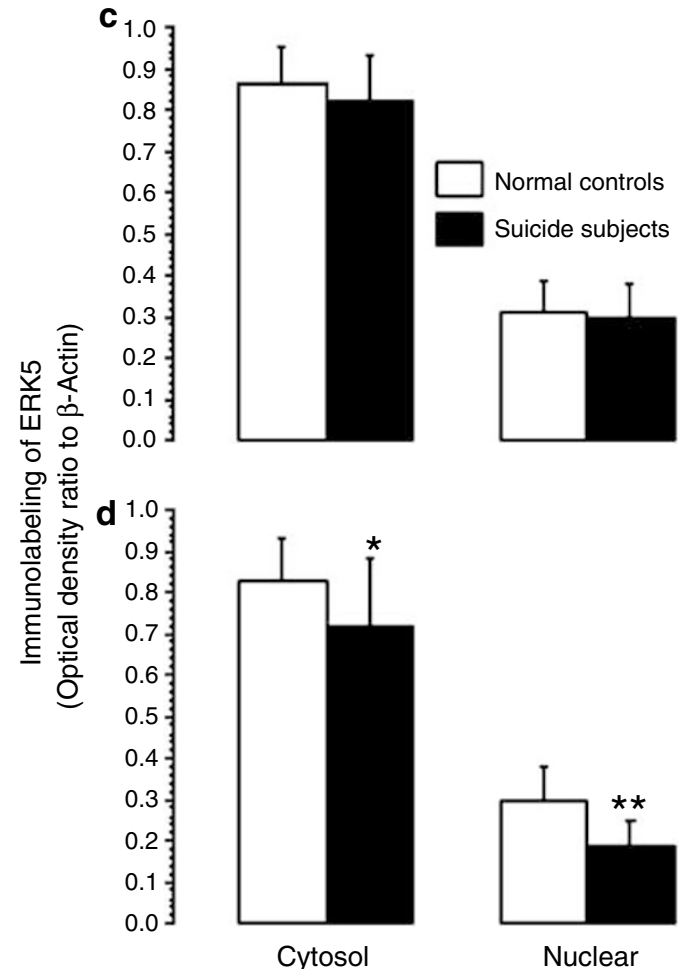

Figure 3 Immunolabeling of ERK5 in the PFC and hippocampus of suicide subjects and controls. Representative Western blots showing the immunolabeling of ERK5 and $\beta$-actin in cytosolic and nuclear fractions of PFC (a) and the hippocampus (b) of four controls and four suicide subjects. Protein samples were subjected to $7.5 \%$ polyacrylamide gel electrophoresis and transferred to ECL-nitrocellulose membranes, which were then incubated with primary antibody specific for ERK5 or $\beta$-actin and corresponding secondary antibody. The bands were quantified as described in Materials and methods. Ratios of the optical density of ERK5 to that of $\beta$-actin were calculated. The mean \pm SD of ERK5 immunolabeling in cytosolic and nuclear fractions of PFC (c) and the hippocampus (d) from controls and suicide subjects. PFC samples were from 21 controls and 28 suicide subjects, and the hippocampus samples were from 21 controls and 21 suicide subjects. Suicide group was compared with control group. $* P<0.02, * * P<0.001$.

The ratios of ERK5 vs cyclophilin mRNAs in the PFC and hippocampus are given in Figure 4d. It was observed that the mRNA level of ERK5 was still significantly decreased in the hippocampus of suicide subjects when expressed as a ratio to cyclophilin $(t=4.58, \mathrm{df}=40, P<0.001)$. There was no significant change in the PFC $(t=0.42, \mathrm{df}=47, P=0.68)$.

\section{MEF2C-DNA-Binding Activity}

MEF2C-DNA-binding activity was determined in the nuclear fraction by gel-mobility shift assay. A representative autoradiogram showing MEF2C-DNA-binding activity in the hippocampus of three controls and three suicide subjects is depicted in Figure $5 \mathrm{a}$ and as a bar diagram in Figure $5 \mathrm{~b}$. As can be seen, MEF2C-DNA activity was significantly decreased in the nuclear fraction of the hippocampus of suicide subjects compared with controls $(t=7.49, \mathrm{df}=40, P<0.001)$. No significant change was noted in PFC of suicide subjects $(t=0.42, \mathrm{df}=47, P=0.68)$ (Figure $5 \mathrm{~b}$ ).

\section{Correlations between: mRNA and Protein Levels of ERK5; Protein Level and Catalytic Activity of ERK5; and Catalytic Activities of ERK5 and MEK5}

We examined whether the decreased protein level of ERK5 in the hippocampus was associated with its mRNA level and whether decreased catalytic activity of ERK5 was associated with its protein level. We observed a significant correlation between the mRNA and the protein levels of ERK5 in both cytosolic ( $r=0.35, P=0.02)$ and nuclear fractions $(r=0.36$, $P<0.02$ ) of the hippocampus. Also significant correlations were noted between the catalytic activity and the protein level of ERK5 in cytosolic $(r=0.31, P=0.04)$ and nuclear $(r=0.36, P=0.019)$ fractions of the hippocampus.

We also examined if the decreased catalytic activity of ERK5 was associated with decreased MEK5 catalytic activity in suicide subjects and found a significant correlation between these two measures $(r=0.42, P=0.005)$.

\section{Effects of Diagnosis and Antidepressants}

To examine whether the various measures of ERK5 and MEK5 as well as in MEF2C-DNA-binding activity, in which we found significant differences, between suicide subjects and normal controls were related to depression or were present in all suicide subjects, we examined the effect of major depression on these measures. For this purpose, we divided the suicide victims into those who were diagnosed with major depression and those who were diagnosed with other psychiatric disorders or had no mental illness. Out of 28 suicide subjects, 12 had major depression. In the suicide group with other psychiatric disorders $(n=16)$, there were five with adjustment, two with schizoaffective disorder, two with bipolar affective disorder, three with drug/alcohol abuse, and three had no diagnosed psychiatric illness; in two suicide subjects the diagnosis was not available. Out of 
a
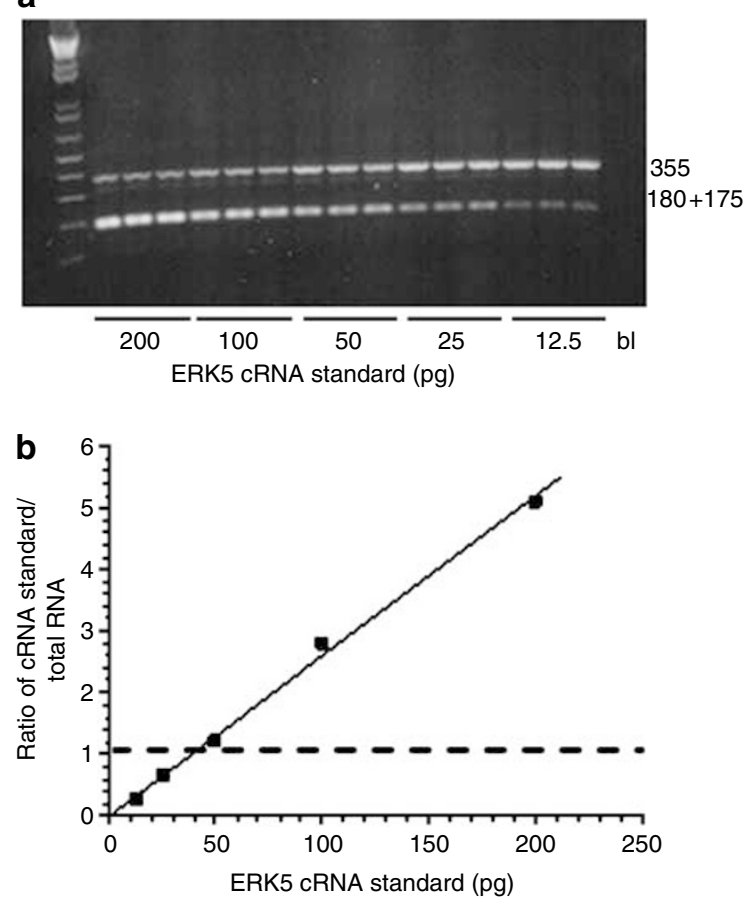

C

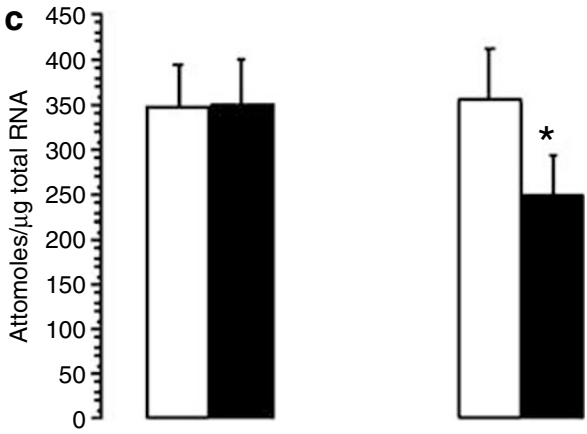

d

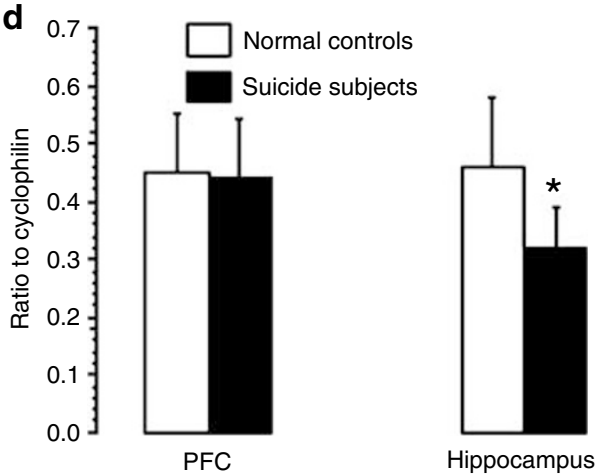

Figure 4 mRNA level of ERK5 in the PFC and hippocampus of suicide subjects and controls. (a) Representative gel electrophoresis showing competitive PCR analysis for ERK5 mRNA contents in the hippocampus obtained from one controls. Decreasing concentrations of standard cRNA (200-12.5 pg) were added to a constant amount $(\mathrm{I} \mu \mathrm{g})$ of total RNA. The mixtures were reverse-transcribed and PCR-amplified in the presence of trace amounts of $\left.{ }^{32} \mathrm{P}\right] \mathrm{dCT}$; aliquots were digested by Xhol and electrophoresed on 1.5\% agarose gel. The higher molecular size band corresponds to the amplification product arising from the mRNA, whereas the lower bands arise from cRNA generated from the internal standard digested by Xhol. bl represent blank. (b) Data derived from the agarose gel are plotted as the counts incorporated into the amplified ERK5 CRNA standard divided by the counts incorporated into the corresponding mRNA amplification product vs the known amount of ERK5 internal standard cRNA added to the test sample. The point of equivalence represents the amount of ERK5 mRNA. mRNA levels of ERK5 (c) and as a ratio to cyclophilin (d) in the PFC and hippocampus of suicide subjects and normal controls. The PFC samples were from 21 controls and 28 suicide subjects, and the hippocampus samples were from 21 controls and 21 suicide subjects. Values are the mean $\pm S D$. Suicide group was compared with control group. $* P<0.001$.

28 suicide subjects, the hippocampus was available from 21 suicide subjects. All the normal controls and suicide subjects for hippocampus studies were the same as described. The hippocampi from these suicide subjects were not available: four suicide subjects with major depression, two suicide subjects whose diagnoses of psychiatric illness was not available, and one suicide subject with adjustment disorder. A one-way ANOVA revealed that catalytic activity and mRNA and protein levels of ERK5; catalytic activity of MEK5, as well as MEF2C-DNA-binding activity were not different between suicide subjects with major depression and suicide subjects with other psychiatric disorders in hippocampus (Table 2). However, both suicide subjects with major depression and suicide subjects with other psychiatric disorders showed significant differences in these measures in the hippocampus when compared with controls (Table 2).

To examine whether the observed changes in measures of ERK5, MEK5, and MEF2C in the hippocampus of the suicide group were related to presence of antidepressant(s), we compared the suicide subjects who tested positive for antidepressants during the screen at the time of death $(n=5)$ and those who did not $(n=23)$. We did not find significant differences in hippocampal mRNA $(t=0.89$, $\mathrm{df}=19, P=0.38$ ), protein levels (cytosol: $t=1.0, \mathrm{df}=19$,
$P=0.31$; nuclear: $t=1.0, \mathrm{df}=19, P=0.32)$, or catalytic activity (cytosol: $t=0.67, \mathrm{df}=19, P=0.51$; nuclear: $t=0.11$, $\mathrm{df}=19, P=0.91)$ of ERK5 between those who showed presence of antidepressants at the screen at the time of death and those who did not. Antidepressants also did not have a significant effects on MEF2C binding activity $(t=1.8$, $\mathrm{df}=19, P=0.08)$. However, the catalytic activity of MEK5 was significantly higher in the group which showed presence of antidepressant during the screen at the time of death $(t=2.8, \mathrm{df}=19, P=0.01)$.

\section{Effects of Confounding Variables}

The effects of potential confounding variables, namely, age, gender, $\mathrm{PMI}$, or $\mathrm{pH}$ of the brain, were evaluated with respect to the various measures in hippocampus in which we had found differences between normal controls and suicide subjects. We found no significant effects of age on mRNA ( $r=0.04, P=0.82$ ) or protein levels of ERK5 (cytosol: $r=0.03, P=0.86$; nuclear: $r=0.08, P=0.59)$; however, the catalytic activity of ERK5 only in cytosolic $(r=0.34$, $P=0.02)$ but not in the nuclear fraction $(r=0.16, P=0.31)$ was negatively correlated with age. A similar negative correlation of cytosolic ERK5 catalytic activity with age was noted in the PFC $(r=0.36, P=0.01)$. On the other hand, age 

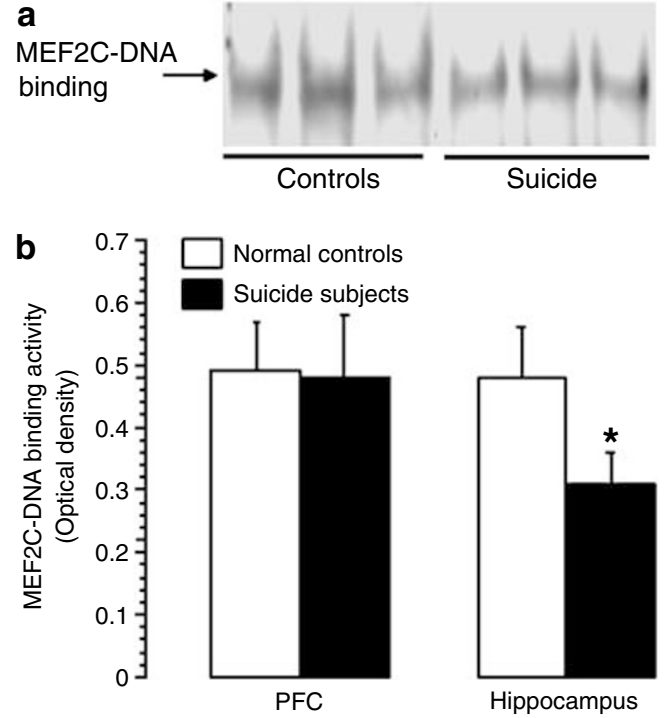

Figure 5 MEF2C-DNA-binding activity in PFC and the hippocampus of suicide subjects and normal controls. (a) A Representative autoradiogram showing MEF2C-DNA-binding activity in nuclear fraction of the hippocampus from three normal controls and three suicide subjects. (b) Mean \pm SD of MEF2C-DNA-binding activity in the PFC and hipppocampus of controls and suicide subjects. PFC samples were from 21 controls and 28 suicide subjects, and the hippocampus samples were from 21 controls and 21 suicide subjects. Suicide group was compared with control group. $* P<0.001$.

had no significant effects on the catalytic activity of MEK5 $(r=0.09, P=0.51)$ or on MEF2C-DNA-binding activity $(r=0.16, P=0.30)$ in hipppocampus. No significant effects of PMI on mRNA ( $r=0.05, P=0.72$ ), protein level (cytosol: $r=0.09, P=0.57$; nuclear: $r=0.10, P=0.51$ ), or catalytic activity (cytosol: $r=0.10, \quad P=0.50$; nuclear: $r=0.22$, $P=0.15$ ) of ERK5 were noted in the hippocampus. The catalytic activity of MEK5 $(r=0.03, P=0.84)$ and MEF2CDNA-binding activity $(r=0.06, P=0.67)$ were also not affected by PMI in this brain area. Furthermore, no significant effects of the $\mathrm{pH}$ of the brain were observed on mRNA $(r=0.06, P=0.70)$, protein levels (cytosol: $r=0.03$, $P=0.84$; nuclear: $r=0.07, P=0.63$ ), catalytic activity of ERK5 (cytosol: $r=0.001, \quad P=0.99$; nuclear: $r=0.17$, $P=0.27)$, or on MEF2-DNA-binding activity $(r=0.24$, $P=0.13)$ in the hippocampus. A significant negative correlation was observed between $\mathrm{pH}$ and MEK5 activity in the hippocampus $(r=0.33, P=0.03)$.

We reanalyzed the data for ERK5 and MEK5 catalytic activities in which we observed significant correlation with age and $\mathrm{pH}$ respectively, and observed that catalytic activities of ERK5 (cytosolic: $\mathrm{df}=2,38, \mathrm{~F}=13.8, P<0.001$; nuclear: $\mathrm{df}=2,38, \mathrm{~F}=14.4, P<0.001)$ and MEK5 $(\mathrm{df}=2,38$, $\mathrm{F}=18.15, P<0.001)$ were still significantly decreased in the hippocampus of suicide subjects as compared with controls.

There were 17 male and four female subjects in the control group. Comparison studies showed no significant differences in any of the measures between male and female subjects in the hippocampus (ERK5 mRNA: $t=0.19$, $\mathrm{df}=19, P=0.85$; ERK5 protein: cytosol, $t=0.19, \mathrm{df}=19$, $P=0.84$; nuclear, $t=1.6, \mathrm{df}=19, P=0.12$; ERK5 catalytic activity: (cytosol, $t=0.44, \mathrm{df}=19, P=0.66$; nuclear, $t=2.0$, $\mathrm{df}=19, P=0.06$; MEK5 catalytic activity: $t=0.03, \mathrm{df}=19$,
$P=0.97$; MEF2C-DNA-binding activity: $t=1.01, \mathrm{df}=19$, $P=0.99$ ).

\section{DISCUSSION}

In the present study, we noted interesting but contrasting results when ERK5 signaling was examined in the PFC and the hippocampus of suicide subjects. Initially, we determined the catalytic activity of ERK5 in both cytosolic and nuclear fractions, because both these fractions contain ERK5 protein (Kato et al, 1997; Raviv et al, 2003). We found that the catalytic activity of ERK5 was greater in the cytosolic fraction than the nuclear fraction. When compared between normal controls and suicide subjects, the catalytic activity of ERK5 was decreased in both cytosolic and nuclear fractions of suicide subjects. This decrease was confined only to the hippocampus, without any change in the PFC. Similar results were noted when the protein level of ERK5 was examined, such that the amount of ERK5 protein was greater in the cytosolic fraction than the nuclear fraction and when compared between controls and suicide subjects, protein level of ERK5 was significantly decreased in both these fractions of the hippocampus of suicide subjects. No significant differences were noted in the PFC. We also observed that the mRNA level of ERK5 was decreased in the hippocampus of suicide subjects. Interestingly, Yan et al (2001) reported three splice variants for ERK5, that is, ERK5a, ERK5b, and ERK5c, in mouse and showed that mouse ERK5a is the most expressed splice variant and shares $91 \%$ homology with human ERK5. They also showed that ERK5b and ERK5c lack a catalytic domain and inhibit ERK5a-mediated MEF2C transactivation, thus acting as dominant negative kinases. Further studies of specific splice variants will be helpful to delineate the role of these variant(s) in suicide.

To examine whether the decreased activation of ERK5 is due solely to the decrease in its expression or whether an upstream kinase is also involved in such decreased activation, we examined the catalytic activity of MEK5, which specifically activates ERK5 (English et al, 1995; Zhou et al, 1995; Kato et al, 1997). MEK5 exists in at least two spliced forms, $\alpha$ and $\beta$. MEK5 $\beta$ is ubiquitously distributed and is primarily cytosolic, whereas MEK5 $\alpha$ is expressed highly in the brain and is present in the particulate fraction (English et al, 1995). As the antibody we used does not distinguish between these two splice variants, we determined the catalytic activity and protein level of MEK5 in the total fraction and found that catalytic activity of MEK was decreased in the hippocampus of suicide subjects without any change in its protein level. No change was observed in catalytic activity as well as protein level of MEK5 in the PFC. It has been shown that both $\alpha$ and $\beta$ splice variants of MEK5 activate ERK5. However, mainly the $\alpha$ isoform is involved in differential subcellular localization of MEK5. This suggests a possible role of MEK5 in generating specificity in ERK5 signaling. Recently, Cameron et al (2004) reported that MEK5 $\beta$ inhibited epidermal growth factor-induced ERK5 activation and MEK $\alpha$-induced MEF2 transcription activity, suggesting dominant negative behavior of MEK5 $\beta$ on ERK5 activation. Further study may clarify which isoform of 


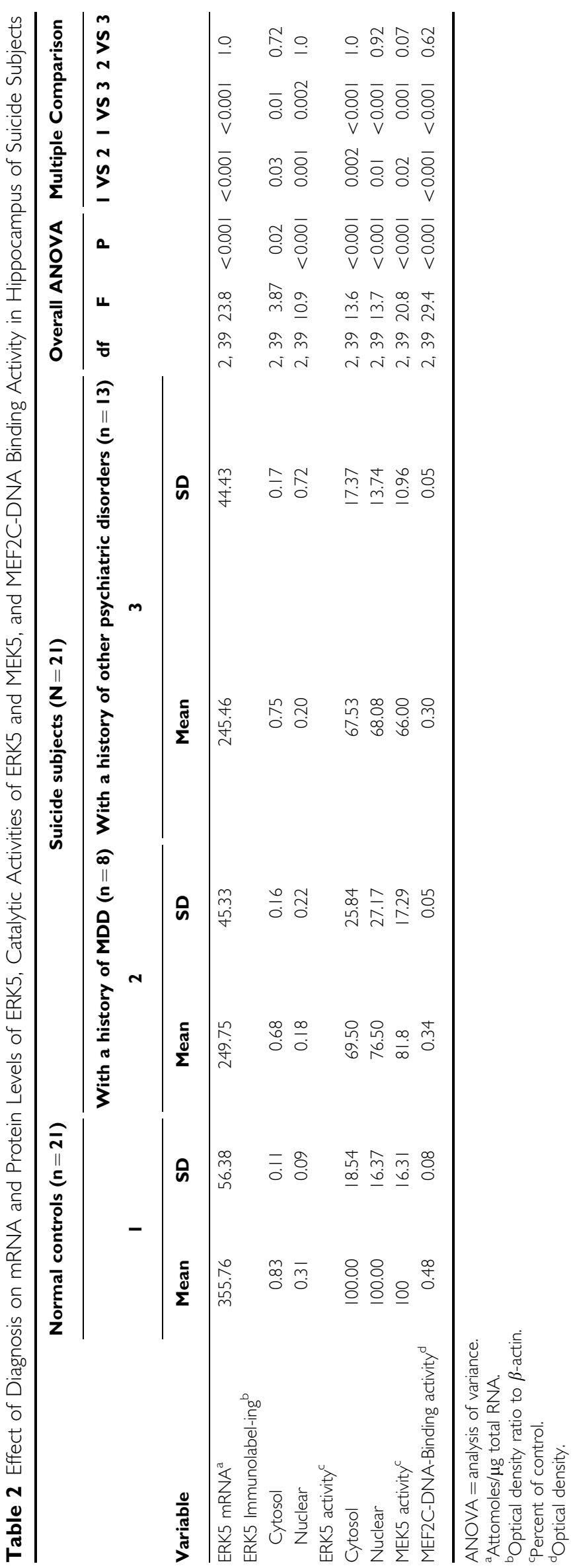

MEK5 is involved in suicide and its respective role in the molecular pathophysiology.

Our correlational data analysis demonstrate significant correlations between the catalytic activity and the protein level of ERK5, as well as between the mRNA and the protein levels of ERK5, which suggests that the decrease in protein level of ERK5 is associated with a decrease in its mRNA level and that the decrease in its catalytic activity could be due to a decrease in the amount of ERK5 present. In addition, we observed a significant correlation between decreased catalytic activities of MEK5 and ERK5, suggesting that besides decreased expression level of ERK5, decreased catalytic activity of ERK5 could also be related to decreased MEK5 activity.

We also investigated the functional response of ERK5 by examining the DNA binding activity of MEF2C. MEF2C is a member of the family of transcription factor MEF2 (Kato et al, 1997; Marinissen et al, 1999) and is highly expressed in developing and adult brain (Leifer et al, 1993, 1994; McDermott et al, 1993; Lyons et al, 1995). Activation of ERK5 leads to phosphorylation and therefore enhanced transactivation capacity of MEF2C (Yang et al, 1998). In this study, we observed that MEF2C-DNA-binding activity was significantly decreased in the nuclear fraction of the hippocampus obtained from suicide subjects.

The observed changes in ERK5, MEK5, and MEF2C were not related to confounding variables, such as PMI, gender, or age of subjects. However, we observed that MEK5 catalytic activity was negatively correlated with $\mathrm{pH}$ of the brain. Interestingly, MEK5 catalytic activity was greater in the hippocampus of those suicide subjects who showed presence of antidepressants at the time of death, which suggests a possible reversal of decreased MEK5 activity by antidepressants. Further studies are required to confirm this finding in a larger number of antidepressant-treated subjects. Because depression is a major factor in suicidal behavior, we determined whether the observed effects on ERK5 signaling were specific to depression by comparing suicide subjects who were diagnosed with major depression with those who had other psychiatric disorders. It was found that the measures of ERK5, MEK5, and MEF2C were altered in all suicide subjects irrespective of psychiatric diagnosis.

Our finding of altered ERK5 only in the hippocampus but not in the PFC suggests brain region-specific changes and signifies a specific role of ERK5 in the hippocampus of suicide subjects. Although this has not been studied, it is quite possible that the ERK5 pathway may be distinctively regulated in different brain areas. It is pertinent to mention that recently we observed that the level of NGF was decreased in the hippocampus of suicide subjects (Dwivedi et al, 2005). Interestingly, it has been reported that internalization and retrogate transport of TrkA, receptors for NGF, activates specifically the ERK5 signaling pathway in neurons (Watson et al, 2001). Also, it has been shown that Epac suppresses muscle-specific A-kinase anchoring protein-associated ERK5 activity in a PKA-independent manner (Dodge-Kafka et al, 2005), and recently, we reported that Epac level is increased in postmortem brain of suicide subjects (Dwivedi et al, 2006). Whether such upstream regulation of ERK5 plays a role in the brain region-specific alteration in ERK5 is not clear and needs to be studied. 
Our finding appears to be important and raises a fundamental question: what is the functional implication of an altered ERK5 pathway in the brain of suicide subjects? Emerging evidence suggests a role for ERK5 during development and in adult CNS functions (reviewed in Cavanaugh, 2004; Wang and Tournier, 2006). Recently, Watson et al (2001) reported that ERK5 is activated locally by NGF in the distal axons of DRG neurons and that activated ERK5 promotes retrograde neuronal survival through activation of p90 ribosomal S6 kinase, which in turn activates another transcription factor, CREB, involved in regulation of the transcription of survival and proapoptotic genes (Watson et al, 2001). ERK5, by directly phosphorylating proapoptotic proteins, such as Bad, participates in cell proliferation and in inhibition of apoptosis (Kato et al, 1998; Wang and Tournier, 2006). Kamakura et al (1999) showed that endogenous c-Fos induction is prevented by inhibition of ERK5 activation and that the MEK5-ERK5 pathway acts on endogenous SRE to express the c-fos gene in PC12 cells. Shalizi et al (2003) demonstrated that BDNF induces the ERK5-MEF2C pathway and thereby stimulates transcription of NT-3, specifically in newly generated granule neurons. Disruption of this pathway abrogated the ability of BDNF to promote the survival of newly generated granule neurons. It is pertinent to mention that we previously reported that expression of NT-3 is significantly reduced in postmortem brain of suicide subjects (Dwivedi et al, 2005). Recently, Wang et al (2004) demonstrated not only the role of NMDA and Ltype voltage-gated ion channel-mediated activation of ERK5 in cerebral ischemia but also showed that activation of ERK5 plays a neuroprotective role in the hippocampus after cerebral ischemia (Wang et al, 2005). More recently, Yoon et al (2005) showed that ECS increased the activation of ERK5 and MEF2C phosphorylation in rat brain, which suggests a possible role of ERK5 in the mechanisms of action of ECS. Thus, given the role of ERK5 signaling in various aspects of physiological functions in the brain, decreased signaling by this pathway in the brain of suicide subjects appears to be significant.

In conclusion, to our knowledge, this is the first study examining ERK5 signaling in psychiatric illness, and demonstrates abnormalities in this signaling cascade at multiple levels in the hippocampus of suicide subjects. Given the importance of the hippocampus in cognitive behavior, and its role in stress and suicide, the decrease in ERK5 signaling in this brain area implicates the possible involvement of ERK5 signaling in the pathogenic mechanisms of suicide.

\section{ACKNOWLEDGEMENTS}

This research was supported by NIMH R0168777 to Dr Y Dwivedi, NIMH RO1MH48153 to Dr GN Pandey, and NIMH R01MH60744 to Dr R Roberts. We have no other financial or conflict of interest to disclose. We thank Miljana Petkovic and Barbara Brown for their help in organizing the brain tissue. We also thank the members of the Maryland Brain Collection for their efforts, particularly in family interviews and dissection. We are grateful for the cooperation of the Office of the Chief Medical Examiner in Baltimore, Maryland.

\section{REFERENCES}

Cameron SJ, Abe J, Malik S, Che W, Yang J (2004). Differential role of MEK5 $\alpha$ and MEK5 $\beta$ in BMK1/ERK5 activation. $J$ Biol Chem 279: $1506-1512$.

Cavanaugh JE (2004). Role of extracellular signal regulated kinase 5 in neuronal survival. Eur J Biochem 271: 2056-2059.

Cavanaugh JE, Ham J, Hetman M, Poser S, Yan C, Xia Z (2001). Differential regulation of mitogen-activated protein kinases ERK1/2 and ERK5 by neurotrophins, neuronal activity, and cAMP in neurons. J Neurosci 2: 434-443.

Chang L, Karin M (2001). Mammalian MAP kinase signaling cascade. Nature 410: 37-40.

Chao TH, Hayashi M, Tapping RI, Kato Y, Lee JD (1999). MEKK3 directly regulates MEK5 activity as part of the big mitogenactivated protein kinase 1 (BMK1) signaling pathway. J Biol Chem 274: 36035-36038.

Chiariello M, Marinissen MJ, Gutkind JS (2000). Multiple mitogenactivated protein kinase signaling pathways connect the cot oncoprotein to the c-jun promoter and to cellular transformation. Mol Cell Biol 20: 1747-1758.

Dodge-Kafka KL, Soughayer J, Pare GC, Carlisle Michel JJ, Langeberg LK, Kapiloff MS, Scott JD (2005). The protein kinase A anchoring protein mAKAP coordinates two integrated cAMP effector pathways. Nature 437: 574-578.

Dwivedi Y, Mondal AC, Rizavi HS, Conley RR (2005). Suicide brain is associated with decreased expression of neurotrophins. Biol Psychiatry 58: 315-324.

Dwivedi Y, Rao JS, Rizavi HS, Kotowski J, Conley RR, Roberts RC et al (2003b). Abnormal expression and functional characteristics of cyclic adenosine monophosphate response element binding protein in postmortem brain of suicide subjects. Arch Genl Psychiatry 60: 273-282.

Dwivedi Y, Rizavi HS, Conley RR, Pandey GN (2006). ERK MAP kinase signaling in post-mortem brain of suicide subjects: differential regulation of upstream Raf kinases Raf-1 and B-Raf. Mol Psychiatry 11: 86-98.

Dwivedi Y, Rizavi HS, Conley RR, Roberts RC, Tamminga CA, Pandey GN (2003a). Altered gene expression of brain-derived neurotrophic factor and receptor tyrosine kinase B in postmortem brain of suicide subjects. Arch Gen Psychiatry 60: 804-815.

Dwivedi Y, Rizavi HS, Roberts RC, Conley RC, Tamminga CA, Pandey GN (2001). Reduced activation and expression of ERK1/ 2 MAP kinase in the postmortem brain of depressed suicide subjects. J Neurochem 77: 916-928.

English JM, Pearson G, Baer R, Cobb MH (1998). Identification of substrates and regulators of the mitogen-activated protein kinase ERK5 using chimeric protein kinases. J Biol Chem 273: $3854-3860$

English JM, Vanderbilt CA, Xu S, Marcus S, Cobb MH (1995). Isolation of MEK5 and differential expression of alternatively spliced forms. J Biol Chem 270: 28897-28902.

Garrington TP, Johnson GL (1999). Organization and regulation of mitogen-activated protein kinase signaling pathways. Curr Opin Cell Biol 11: 211-218.

Harrison PJ, Heath PR, Eastwood SL, Burnet PW, McDonald B, Pearson RC (1995). The relative importance of premortem acidosis and postmortem interval for human brain gene expression studies: selective mRNA vulnerability and comparison with their encoded proteins. Neurosci Lett 200: 151-154.

Hsiung SC, Adlersberg M, Arango V, Mann JJ, Tamir H, Liu KP (2003). Attenuated $5-\mathrm{HT}_{1 \mathrm{~A}}$ receptor signaling in brains of suicide victims: involvement of adenylyl cyclase, phosphatidylinositol 3-kinase, Akt and mitogen-activated protein kinase. J Neurochem 87: 182-194.

Johnson GL, Lapadat R (2002). Mitrogen-activated protein kinase pathways mediated by ERK, JNK, and P38 protein kinases. Science 298: 1911-1912. 
Kamakura S, Moriguchi T, Nishida E (1999). Activation of the protein kinase ERK5/BMK1 by receptor tyrosine kinases. J Biol Chem 274: 26563-26571.

Kasler HG, Victoria J, Duramad O, Winoto A (2000). ERK5 is a novel type of mitogen-activated protein kinase containing a transcriptional activation domain. Mol Cell Biol 20: 8382-8389.

Kato Y, Kravchenko VV, Tapping RI, Han J, Ulevitch J, Lee JD (1997). BMK1/ERK5 regulates serum-induced early gene expression through the transcription factor MEF2C. EMBO J 16: 7054-7066.

Kato Y, Tapping RI, Huang S, Watson MH, Ulevitch RJ, Lee JD (1998). BMK1/ERK5 is required for cell proliferation induced by epidermal growth factor. Nature 395: 713-716.

Lee JD, Ulevitch RJ, Han J (1995). Primary structure of BMK1: a new mammalian MAP kinase. Biochem Biophys Res Commun 213: 715-724.

Leifer D, Golden J, Kowall NW (1994). Myocyte-specific enhancer binding factor $2 \mathrm{C}$ expression in human brain development. Neuroscience 63: 1067-1079.

Leifer D, Kraine D, Yu YT, McDermott J, Breitbart RE, Heng J et al (1993). MEF2C, a MADS/MEF2-family transcription factor expressed in a laminar distribution in cerebral cortex. Proc Natl Acad Sci USA 90: 1546-1550.

Liu L, Cavanaugh JE, Wang Y, Sakagami H, Mao Z, Xia Z (2003). ERK5 activation of MEF2-mediated gene expression plays a critical role in BDNF-promoted survival of developing but not mature cortical neurons. Proc Natl Acad Sci USA 100: 8532-8537.

Liu L, Cundiff P, Abel G, Wang Y, Faigle R, Sakagami H et al (2006). Extracellular signal-regulated kinase (ERK) 5 is necessary and sufficient to specify cortical neuronal fate. Proc Natl Acad Sci USA 103: 9697-9702.

Lowry OH, Rosebrough NJ, Farr AL, Randall RJ (1951). Protein measurement with the folic phenol reagent. J Biol Chem 193: 266-275.

Lyons GE, Micales BK, Schwarz J, Martin JF, Olson EN (1995). Expression of MEF2 genes in the mouse central nervous system suggests a role in neuronal maturation. J Neurosci 15: 5727-5738.

Marinissen MJ, Chiariello M, Pallante M, Gutkind JS (1999). A network of mitogen-activated protein kinases links $G$ proteincoupled receptors to the c-jun promoter: a role for c-jun $\mathrm{NH}_{2}$ terminal kinase, p38 s, and extracellular signal-regulated kinase 5. Mol Cell Biol 19: 4289-4301.

McDermott JC, Cardoso MC, Yu YT, Andres V, Leifer D, Kraine D et al (1993). hMEF2C gene encodes skeletal muscle- and brainspecific transcription factors. Mol Cell Biol 13: 2564-2577.

Pearson G, English JM, White MA, Cobb MH (2001b). ERK5 and ERK2 cooperate to regulate NF-kB and cell transformation. J Biol Chem 276: 7927-7931.

Pearson G, Robinson F, Beers GT, Xu BE, Karandikar M, Berman K et al (2001a). Mitogen-activated protein (MAP) kinase pathways regulation and physiological functions. Endocr Rev 22: 153-183.

Raviv Z, Kalie E, Seger R (2003). MEK5 and EK5 are localized in the nuclei of resting as well as stimulated cells, while MEKK2 translocates from the cytosol to the nucleus upon stimulation. J Cell Sci 117: 1773-1784.

Robinson MJ, Cobb MH (1997). Mitogen-activated protein kinase pathways. Curr Opin Cell Biol 9: 180-186.

Salzman S, Clayton P, Winokur G (1983). Diagnostic Evaluation After Death (DEAD). National Institute of Mental Health, Neuroscience Research Branch: Rockville, MD.

Shalizi A, Lehtinen M, Gaudilliere B, Donovan N, Han J, Konishi Y et al (2003). Characterization of a neurotrophin signaling mechanism that mediates neuron survival in the temporally specific pattern. $J$ Neurosci 23: 7326-7336.

Spitzer RL, Williams JBW, Gibbon M, First MB (1995). Structured Clinical Interview for DSM-IV (SCID). New York State Psychiatric Institute, Biometrics Research: New York.

Sun W, Kesavan K, Schaefer BC, Garrington TP, Ware M, Johnson $\mathrm{NL}$ et al (2001). MEKK2 associates with the adapter protein Lad/R1BP and regulates the MEK5-BMK1/ERK5 pathway. J Biol Chem 276: 5093-5100.

Terasawa K, Okazaki K, Nishida E (2003). Regulation of c-Fos and Fra-1 by the MEK5-ERK5 pathway. Gen Cells 8: 263-273.

Wang R-M, Zhang Q-G, Li C-H, Zhang G-Y (2005). Activation of extracellular signal-regulated kinase 5 may play a neuroprotective role in hippocampal CA3/DG region after cerebral ischemia. J Neurosci Res 80: 391-399.

Wang R-M, Zhang Q-G, Zhang G-Y (2004). Activation of ERK5 is mediated by $n$-methyl-D-aspartate receptor and L-type voltagegated calcium channel via Src involving oxidative stress after cerebral ischemia in rat hippocampus. Neurosci Lett 357: 13-16.

Wang X, Tournier C (2006). Regulation of cellular functions by the ERK5 signalling pathway. Cell Signal 18: 753-760.

Watson FL, Heerssen HM, Bhattacharyya A, Klesse L, Lin MZ, Segal RA (2001). Neurotrophins use the ERK5 pathway to mediate a retrograde survival response. Nat Neurosci 4: 981-988.

Yan C, Luo H, Lee J-D (2001). Molecular cloning of mouse ERK5/ BMK1 splice variants and characterization of ERK5 functional domains. J Biol Chem 276: 10870-10878.

Yan L, Carr J, Ashby PR, Murry-Tait V, Thomson C, Arthur JS (2003). Knockout of ERK5 causes multiple defects in placental and embryonic development. BMC Dev Biol 3: 11.

Yang CC, Ornatsky OI, McDermott JC, Cruz TF, Prody CA (1998). Interaction of myocyte enhancer factor 2 (MEF2) with a mitogen-activated protein kinase, ERK5/BMK1. Nucleic Acids Res 26: 4771-4777.

Yoon SC, Ahn YM, Jun SJ, Kim Y, Kang UG, Park JB et al (2005). Region-specific phosphorylation of ERK5-MEF2C in the rat frontal cortex and the hippocampus after electroconvulsive shock. Prog Neuropsychopharmacol Biol Psychiatry 29: 749-753.

Zhou G, Bao ZQ, Dixon JE (1995). Components of a new human protein kinase signal transduction pathway. J Biol Chem 270: 12665-12669. 